\title{
Animal performance, carcass quality and economics of cattle finished after grazing endophyte-infected, endophyte-free or nonergot alkaloid-producing endophyte-infected tall fescue
}

\author{
S. K. DUCKETT ${ }^{1}$, R. C. LACY' , J. G. ANDRAE ${ }^{1}$, C. S. HOVELAND ${ }^{2}$, J. H. BOUTON ${ }^{2}$ and M. A. MCCANN ${ }^{2}$ \\ ${ }^{I}$ Clemson University, Clemson, $S C$ \\ ${ }^{2}$ University of Georgia, Athens, GA \\ sducket@clemson.edu
}

\begin{abstract}
Angus-cross steers grazed wild type endophyte-infected (E+), nonergot alkaloid-producing endophyte-infected (AR542), or endophyte-free (E-) tall fescue pastures at two locations. Twenty-four animals per location were transported to a research feedlot after the completion of the grazing phase and fed for $100 \mathrm{~d}$. Grazing average daily gain (ADG) was $0.47 \mathrm{~kg} / \mathrm{d}$ greater $(\mathrm{P}=0.001)$ for cattle grazing $\mathrm{AR} 542$ than those grazing $\mathrm{E}+$ pastures. In the feedlot, overall ADG did not differ among AR542 and $\mathrm{E}+(\mathrm{P}=0.40)$ or $\mathrm{AR} 542$ and $\mathrm{E}-(\mathrm{P}=0.19)$, and averaged 2.09 $\pm 0.15 \mathrm{~kg} / \mathrm{d}$ across all treatments. Feed efficiency was greater $(\mathrm{P}=0.02)$ for $\mathrm{E}+$ than AR542. Hot carcass weight was $40 \mathrm{~kg}$ greater $(\mathrm{P}=0.01)$ for AR542 than $\mathrm{E}+$. Other carcass traits did not differ $(\mathrm{P} \geq 0.10)$ among treatments. Net present values (NPV) were $\$ 177.08 /$ ha for E- and \$336.76/ha for AR542 compared to E+.
\end{abstract}

Keywords: beef, endophyte, carcass

\section{Introduction}

Tall fescue (Festuca arundinacea Schreb.) is the predominant cool season perennial grass in the eastern U.S., occupying more than 14 million ha (Stuedemann \& Hoveland 1988). Cattle grazing forage from endophyte-infected tall fescue pastures suffer from a condition known as "fescue toxicosis", which results in lower weight gain, elevated body temperature, and failure to shed winter hair coats (Hoveland et al. 1983, 1997; Stuedemann \& Thompson 1993). Fescue toxicosis results from the ingestion of toxic ergot alkaloids produced by a wild-type fungal endophyte (Neotyphodium coenophialum). One alternative to improve animal performance has been to replace toxic endophyte-infected pastures with endophyte-free tall fescue. However, endophytefree tall fescue is relatively intolerant of drought and heavy defoliation (Hill et al. 1991; Bouton et al. 1993). Recently, endophytes that produce no ergot alkaloids have been identified and incorporated into tall fescue varieties (AR542; Bouton et al. 2002). To date, animals grazing AR542 tall fescue perform at equivalent levels to animals grazing endophyte-free pastures (Bouton et al. 2002; Parish et al. 2003a, 2003b) and plant persistence remains equivalent to tall fescue infected with wildtype endophyte (Bouton et al. 2002).

Lusby et al. (1990) found that cattle previously grazed on endophyte-infected fescue pastures can make significant compensatory gains during the first $50 \mathrm{~d}$ in the feedlot. Cole et al. (2001) also reported that steers from pastures with high endophyte infestation compensate for poor pasture performance in the feedlot. However, no information is available on subsequent feedlot performance and net present values to determine the economic feasibility of replacing E+ pastures with AR542. The objective of this study was to determine the subsequent feedlot performance, carcass quality, and economics of cattle that previously grazed E+, E- and AR542 tall fescue pastures.

\section{Methods}

\section{Animals}

Replicated 0.8-ha paddocks (six paddocks/location) of tall fescue monocultures were established at two locations in GA. At each location, two paddocks (two paddocks/endophyte treatment; six paddocks/location) contained tall fescue with one of three endophyte types: non-ergot alkaloid-producing endophyte infected (AR542), endophyte-free (E-) or wild-type, endophyte infected $(\mathrm{E}+)$. The AR542 tall fescue was determined to produce negligible toxic ergot alkaloids when inserted into their tall fescue cultivar host and support animal gains similar to those provided by endophyte-free tall fescue pastures (Bouton et al. 2002). The AR542 tall fescue is commercially available and marketed by Pennington Seed (Madison, GA) under the trade name MaxQ.

At location 1, Angus x Hereford steers $(365 \mathrm{~kg})$ were randomly assigned to paddocks ( $\mathrm{L} 1 ; 4 \mathrm{hd} /$ pasture replicate; two pasture replicates/endophyte type) and grazed for $99 \mathrm{~d}$. At location 2, Angus x Hereford steers $(318 \mathrm{~kg})$ were randomly assigned to treatment paddocks (L2; 4 hd/pasture replicate; two pasture replicates/endophyte type) and grazed for $89 \mathrm{~d}$. Animal weights were collected at 28-day intervals during the grazing study. At the end of the grazing period, final weights were collected after a 16-h fast.

At the completion of the grazing study, all cattle were transported by group to a research feedlot in Oklahoma. Upon arrival at the feedlot, cattle were weighed and rectal temperature was recorded. Cattle were maintained in the same groups as allotted to experimental grazing paddocks and the pen served as the experimental unit for data analyses. Cattle were gradually adapted to a high concentrate diet using three-step-rations fed for $7 \mathrm{~d}$ each and then the final ration for the remainder of the finishing period. Animal weights were collected at 28-day intervals during the finishing phase. Pen feed intake was recorded on a daily basis and cattle were weighed on d 28, 56, 84 and prior to slaughter.

Table 1 Effects of endophyte type on average daily gains (ADG) in the grazing and finishing phase.

\begin{tabular}{lccccc}
\hline & & --- Average daily gain $(\mathrm{kg} / \mathrm{d})---$ & \multicolumn{2}{c}{---- Probability level ----- } \\
& E- & AR542 & E+ & AR542 vs. E- & AR542 vs. E+ \\
\hline Grazing & 1.21 & 1.13 & 0.66 & 0.26 & 0.004 \\
Finishing & 2.01 & 2.17 & 2.08 & 0.19 & 0.40 \\
\hline
\end{tabular}


Table 2 Effects of endophyte type on carcass characteristics.

\begin{tabular}{lccccc}
\hline & \multicolumn{3}{c}{--- Average daily gain $(\mathrm{kg} / \mathrm{d})$--- } & \multicolumn{2}{c}{---- Probability level ----- } \\
& E- & AR542 & E+ & AR542 vs. E- & AR542 vs. E+ \\
\hline Hot carcass wt, $\mathrm{kg}$ & 365 & 380 & 341 & 0.10 & 0.002 \\
Fat thickness, cm & 1.21 & 1.32 & 1.24 & 0.28 & 0.39 \\
Ribeye area, cm2 & 82.46 & 85.94 & 81.17 & 0.25 & 0.13 \\
Marbling score1 & 4.58 & 4.87 & 4.60 & 0.45 & 0.50 \\
Yield grade & 2.87 & 2.97 & 2.74 & 0.66 & 0.30 \\
Quality grade1 & 4.44 & 4.92 & 4.25 & 0.20 & 0.09 \\
Price, $\$$ /kg & 2.43 & 2.50 & 2.36 & 0.09 & 0.01 \\
Value, $\$$ & 892 & 954 & 808 & 0.08 & 0.003 \\
\hline
\end{tabular}

${ }^{1}$ Marbling score/Quality grade: $4.00=$ slight/Select; $5.00=$ small/Choice.

Cattle groups were slaughtered when the average fat thickness, as determined by visual observation, reached $1.27 \mathrm{~cm}$. At the end of the study, final weights were collected after a 16-h fast. All cattle in each group, regardless of treatment, were slaughtered at a similar time-on-feed endpoint. Carcass data (hot carcass weight, fat thickness, LM area, KPH, marbling score, quality grade, and yield grade) were collected from each carcass at 24 $\mathrm{h}$ postmortem.

\section{Economic analyses}

Animal performance and carcass data were used in an economic analysis to determine the financial implications of this research. Differences in net income (NI) per head among the treatments were calculated for the grazing phase (GRAZING), finishing phase (FINISHING), and the overall grazing though finishing phase (OVERALL). These NI were then converted to dollars/ ha $(\mathrm{NI} / \mathrm{HA})$ to determine the ultimate impact on profits from the three types of tall fescue. Differences in NI/HA were then used to calculate net present values to determine the profitability of replacing E+ with either AR542 or E-. Once NI/HA was calculated for all three endophyte types in the GRAZING, FINISHING, and OVERALL phases, they were combined with estimated stand life, interest rate, and establishment cost (Parish et al. 2003b) to calculate the net present values (NPV) of E- and AR542 compared to E+.

\section{Statistical analyses}

Data were analysed as a mixed linear model (SAS Inst. Inc., Cary, NC) to account for the fixed effects of endophyte type, location, and two-way interaction, and the random effects of pen. Experimental unit was pen. All interactions between endophyte type and location were non-significant $(\mathrm{P} \geq 0.13)$ and least squares means are presented in the tables by main effects of endophyte treatment and group. Preplanned, nonorthogonal contrasts were used to test the effects of non-ergot alkaloid-producing endophyte-infected tall fescue versus wild type, endophyteinfected (AR542 vs. E+) or versus endophyte-free (AR542 vs. E) tall fescue. Significance was determined at $P \leq 0.05$. Differences of $\mathrm{P}>0.05$ to $\mathrm{P}<0.10$ are discussed as trends.

\section{Results}

Grazing average daily gain (ADG) was $0.47 \mathrm{~kg} / \mathrm{d}$ greater $(\mathrm{P}=0.01)$ for cattle grazing AR542 than those grazing $\mathrm{E}+$ pastures
(Table 1). Live weights of cattle off pasture were $68 \mathrm{~kg}$ greater $(\mathrm{P}=0.01)$ for $\mathrm{AR} 542$ than $\mathrm{E}+$, and did not differ $(\mathrm{P}=0.17)$ among AR542 and E-. Transit shrink on a weight or percentage basis did not differ among AR542 and $\mathrm{E}+(\mathrm{P}>0.10)$, or AR542 and E- $(\mathrm{P}>0.93)$. Rectal temperatures at feedlot arrival $(\mathrm{P}=0.01)$ were higher for $\mathrm{E}+$ than $\mathrm{AR} 542$. In the feedlot, overall $\mathrm{ADG}$ did not differ among AR542 and $\mathrm{E}+(\mathrm{P}=0.40)$ or AR542 and $\mathrm{E}-$ $(\mathrm{P}=0.19)$, and averaged $2.09+0.15 \mathrm{~kg} / \mathrm{d}$ across all treatments. Feed efficiency was greater $(\mathrm{P}=0.02)$ for $\mathrm{E}+$ than AR542. Hot carcass weight was $40 \mathrm{~kg}$ greater $(\mathrm{P}=0.01)$ for $\mathrm{AR} 542$ than $\mathrm{E}+$ (Table 2). Other carcass traits did not differ $(\mathrm{P}>0.10)$ among AR542 and E+, or AR542 and E-. Carcass value was greater $(\mathrm{P}<0.01)$ for AR542 than $\mathrm{E}+$ due to advantages in carcass weight. Net present values (NPV), a financial measure to indicate relative profitability of an investment over time, were \$177.08/ha for Eand $\$ 336.76 /$ ha for AR542. These NPV values indicate that it would be economically advantageous to replace $\mathrm{E}+$ pastures with AR542 or E-; however, the economic incentive is greater for AR542 due to greater agronomic persistence.

\section{Discussion}

Steers grazing E+ tall fescue had lower weight gains during the grazing phase than AR542, which was similar to E-. However, average daily gains did not differ among endophyte types during the finishing phase after removal from grazing treatments. Similarly, others have reported overall ADG among cattle that previously grazed endophyte infected versus endophyte-free tall fescue pastures (Allen et al. 2001) or orchardgrass and bromegrass pastures interseeded with red clover (Hancock et al. 1987) and controls. Conversely, others have reported higher ADG for cattle that previously grazed endophyte infected tall fescue at high versus low infection levels during the initial 6-d holding period on bermudagrass pastures (Lusby et al. 1990) or the initial $14 \mathrm{~d}$ in the feedlot (Cole et al. 2001).

Feed intake as a percentage of body weight was lower for E+ and feed efficiency was greater. Beconi et al. (1995) also reported lower feedlot DMI intakes for steers previously fed E+ haylage compared to E- haylage. Conversely, others have reported no reduction in feedlot DMI for cattle that previously grazed E+ with high infestation levels compared to low infestation levels (Cole et al. 2001), E+ with ladino clover or E- (Coffey et al. 1990), or bromegrass-red clover or orchardgrass-red clover (Hancock et al. 1987), or E- (Allen et al. 2001). Beconi et 
al.(1995) reported improvement in feed efficiency during the first $28 \mathrm{~d}$ in the feedlot for cattle that previously consumed $\mathrm{E}+$ versus E- tall fescue pastures. Cole et al. (2001) reported linear increases in feed efficiency for cattle finished after grazing tall fescue pastures with increasing levels of endophyte infestation. Allen et al. (2001) reported improvements in feed efficiency for cattle finished after grazing E+ compared to E- pastures. Coffey et al. (1990) also reported improved feed efficiency for steers that previously grazed $\mathrm{E}+$ versus $\mathrm{E}+$ with ladino clover or E-. In contrast, Hancock et al. (1987) did not observe any differences in feedlot gain, DMI or feed efficiency of steers that previously grazed $\mathrm{E}^{+}$, bromegrass-red clover, or orchardgrass clover pastures. Carcass value was greater for AR542 than E+ due to advantages in hot carcass weight; however, other carcass traits were unaffected by endophyte type. Similarly, others (Coffey et al. 1990; Allen et al. 2001; Realini et al. 2005) have reported similar results in that the only carcass trait influenced by endophyte treatment was $\mathrm{HCW}$ as a result of poorer performance during the grazing phase.

NPV is a financial measure that indicates the relative profitability of an investment over time. It takes into consideration difference in the amount of investment (establishment cost), useful life (stand life), cash flow (NI), and interest rate. Alternatives with a positive NPV will be profitable while those with a negative NPV will not. When comparing two alternatives, the one with the highest NPV would be preferred. In this study, E-yielded a NPV of \$177.08/ha while AR542 showed a NPV of \$336.76/ha. These results indicate that producers who have high infestation levels of $\mathrm{E}+$ in their pastures would benefit economically if $\mathrm{E}+$ was replaced with either E- or AR542. Much of the economic incentive for this decision is derived from the savings in feeding costs once the animals reach the feedlot. Calves grazed on E+ weighed less and thus had a higher overall feeding cost than calves grazed on either AR542 or E-. When comparing the differences in NPV between E- and AR542, producers have an economic incentive of about $\$ 160 /$ ha or about $2: 1$ to replace E+ with AR542 instead of E-. This occurs despite the higher establishment cost per hectare of AR542. The primary reason AR542 is more profitable than E- is due to the longer stand life of AR542. Sensitivity analysis reveals that it takes approximately 3 years of grazing for E- to breakeven and 5 years for AR542.

\section{REFERENCES}

Allen, V.G.; Pond, K.R.; Saker, K.E.; Fontenot, J.P.; Bagley, C.P.; Ivy, R.L.; Evans, R.R.; Brown, C.P.; Miller, M.F.; Montgomery, J.L.; Dettle, T.M.; Wester, D.B. 2001. Tasco-Forage: III. Influence of a seaweed extract on performance, monocyte immune cell response, and carcass characteristics in feedlotfinished steers. Journal of Animal Science 79: 1032-1040.

Beconi, M.G; Howard, M.D.; Forbes; T.D.A.; Muntifering, R.B.; Bradley, N.W.; Ford, M.J. 1995. Growth and subsequent feedlot performance of estradiol-implanted vs. nonimplanted steers grazing fall-accumulated endophyte-infested or low-endophyte tall fescue. Journal of Animal Science 73: 1576-1584.

Bouton, J.H.; Latch, G.C.M.; Hill, N.S.; Hoveland, C.S.; McCann, M.A.; Watson, R.H.; Parish, J.A.; Hawkins, L.L.; Thompson, F.N. 2002. Re-infection of tall fescue cultivars with non-ergot alkaloid producing endophytes. Agronomy Journal 94: 567-574.

Bouton, J.H., Gates, R.N.; Hoveland, C.S.; Wood, D.T. 1993. Yield and persistence of tall fescue in the southeastern coastal plain after removal of its endophyte. Agronomy Journal 85: 52-55.

Coffey, K.P.; Lomas, L.W.; Moyer, J.L. 1990. Grazing and subsequent feedlot performance by steers that grazed different types of fescue pasture. Journal of Production Agriculture 3: 415-420.

Cole, N.A.; Stuedemann, J.A.; Thompson, F.N. 2001. Influence of both endophyte infestation in fescue pastures and calf genotype on subsequent feedlot performance of steers. Professional Animal Scientist 17: 174-182.

Hancock, D.L.; Williams, J.E.; Hedrick, H.B.; Beaver, E.E.; Larrick, D.K.; Ellersieck, M.R.; Garner, G.B.; Morrow, R.E.; Paterson, J.A.; Gerrish, J.R. 1987. Performance, body composition, carcass characteristics of steers as influenced by previous forage systems. Journal of Animal Science 65: 1381-1391.

Hill, N.S.; Belesky, D.P.; Stringer, W.C. 1991. Competitiveness of tall fescue as influenced by Acremonium coenothialum. Crop Science 31: 185-190.

Hoveland, C.S.; McCann, M.A.; Bouton, J.H. 1997. Influence of endophyte, alfalfa, and grazing pressure on steer performance and plant persistence of Jesup tall fescue. Journal of Production Agriculture 10: 546-550.

Hoveland, C.S.; Schmidt, S.P.; King, C.C.; Odom, J.W.; Clark, E.M.; McGuire, J.A.; Smith, L.A.; Grimes, H.W.; Holliman, J.A. 1983. Steer performance and association of Acremonium coenophialam fungal endophyte on tall fescue pasture. Agronomy Journal 75: 821-824.

Lusby, K.S.; McMurphy, W.E.; Strasia, C.A.; Smith, S.C.; Muntz, S.H. 1990. Effects of fescue endophyte and interseeded clovers on subsequent finishing performance of steers. Journal of Production Agriculture 3: 103-105.

Parish, J.A.; McCann, M.A.; Watson, R.H.; Hoveland, C.S.; Hawkins, L.L.; Hill, N.S.; Bouton, J.H. 2003a. Use of nonergot alkaloid-producing endophytes for alleviating tall fescue toxicosis in sheep. Journal of Animal Science 81: 1316-1322.

Parish, J.A.; McCann, M.A.; Watson, R.H.; Paiva, N.N.; Hoveland, C.S.; Parks, A.H.; Upchurch, B.L.; Hill, N.S.; Bouton, J.H.. 2003b. Use of nonergot alkaloid-producing endophytes for alleviating tall fescue toxicosis in stocker cattle. Journal of Animal Science 81: 2856-2868.

Realini, C.E.; Duckett, S.K.; Hill, N.S.; Hoveland, C.S.; Lyon, B.G.; Sackmann, J.R.; Gillis, M.H. 2005. Effect of endophyte type on carcass traits, meat quality, and fatty acid composition of beef cattle grazing tall fescue. Journal of Animal Science 83:430-439.

Stuedemann, J.A.; Hoveland, C.S. 1988. Fescue endophyte: History and impact on animal agriculture. Journal of Production Agriculture 1: 39-44.

Stuedemann, J.A.; Thompson, F.N. 1993. Management strategies and potential opportunities to reduce the effects of endophyteinfected tall fescue on animal performance. pp. 1-12 In:. Proc. $2^{\text {nd }}$ International. Symposium on Acremonium/Grass Interactions, Plenary Papers. Hume, D.E.; Latch, G.C.M.; Easton, H.S. 1993. AgResearch, Grasslands Research Centre, Palmerston North, New Zealand. 